\title{
Sub-acute Toxicity Study of The Ethyl Acetate Fraction of Asam Kandis Rinds (Garcinia cowa Roxb.) on the Liver and Renal Func- tion in Mice
}

\author{
Fatma Sri Wahyuni ${ }^{1}$, Dessy Arisanty ${ }^{2}$, Nelsi Fitri Hayaty ${ }^{1}$, Dian Ayu Juwita ${ }^{1}$, Almahdy ${ }^{1 *}$
}

\begin{abstract}
Objective: The present study investigated the sub acute toxicity of the ethyl acetate fraction of asam kandis (Garcinia cowa Roxb) Rinds in mice. Material and Methods: Sub acute toxicity study was carried out by giving orally at dose 500, 1000 dan $2000 \mathrm{mg} / \mathrm{kgBW}$ extract to five mice at 21 days. Animals were observed individually for any clinical signs of toxicity or mortality for 14 days. Measured parameters were SGPT levels, serum creatinine levels, weight ratio of liver and kidney. Extract was given orally at dose 500, 1000 and $2000 \mathrm{mg} / \mathrm{kgBW}$ for 21 days. Observations were done on day 8th, 15th and 22th using blood serum, liver and kidneys of mice. Data were analyzed by using two-way ANOVA followed by Duncan's Multiple Range Test. Results: The ethyl acetate fraction of G. cowa at doses 500, 1000 and $2000 \mathrm{mg} / \mathrm{kgBW}$ gave significant effect on increasing SGPT levels and decreasing levels of serum creatinine $(p<0.05)$. The length of treatment gave significant effect on decreasing levels of serum creatinine, weight ratio of liver and kidney $(p<0.05)$. Conclusion: The dosage of the ethyl acetate fraction of asam kandis rinds provides significant effect on the SGPT and serum creatinine levels of male white mice. The duration of administration of ethyl acetate fraction of asam kandis rinds provides significant effect on serum creatinine levels, the weight ratio of liver and kidney organ of male white mice.
\end{abstract}

Key words: Sub-acute toxicity, Garcinia cowa rinds, SGPT, Creatinine serum, Weight ratio of liver and kidney.

\section{Fatma Sri Wahyuni ${ }^{1}$, Dessy Ari- santy ${ }^{2}$, Nelsi Fitri Hayaty', Dian Ayu Juwita ${ }^{1}$, Almahdy ${ }^{1 *}$ \\ 'Faculty of Pharmacy, Andalas Univer- sity, West Sumatera, INDONESIA. \\ ${ }^{2}$ Faculty of Medicine, Andalas University, West Sumatera, INDONESIA.}

\section{Correspondence}

\section{Almahdy,}

Faculty of Pharmacy, Andalas University, Kampus Limau Manis, Padang, West Sumatra, INDONESIA.

Phone no: +6275171682

E-mail: almahdya@gmail.com

History

- Submission Date: 18-11-16;

- Review completed: 05-01-17;

- Accepted Date: 02-02-17.

DOI : 10.5530/pj.2017.3.58

Article Available online http://www.phcogj.com/v9/i3

\section{Copyright}

(c) 2017 Phcog.Net. This is an openaccess article distributed under the terms of the Creative Commons Attribution 4.0 International license.

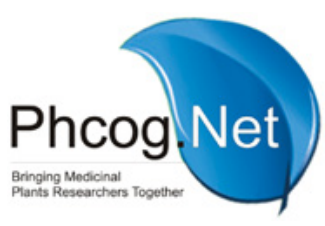

\section{INTRODUCTION}

Garcinia (Guttiferae) species are commonly found in the lowland areas of the rainforests. They consist of about 400 species concentrated mainly in southeast Asia. ${ }^{1}$ Garcinia species are typically small to medium evergreen fruit trees, and usually produce hard timber. Traditional uses and medicinal properties of this species were documented by Burkill. ${ }^{2}$

The chemical constituents and biological activity of Garcinia (Guttiferae) has been extensively investigated. This genus is reported to contain quinone, ${ }^{3}$ xanthones, ${ }^{3,4}$ benzophenones, ${ }^{5}$ triterpenes, ${ }^{6}$ biflavonoids ${ }^{7}$ and benzoquinone. ${ }^{8}$ The pharmacological activities of this genus were anticancer, ${ }^{9,10}$ anti-inflammatory, ${ }^{11}$ antibacterial, ${ }^{12}$ antiviral, ${ }^{13}$ antifungal and antioxidants. ${ }^{14}$

G. cowa, commonly known as asam kandis in Indonesia, is widely distributed throughout Indonesia, Malaysia, Thailand and Myanmar. Many parts of $G$. cowa have been used in traditional folk medicine. For example, the bark, latex and root have been used as an anti fever agent ${ }^{15,16}$ while the fruit and leaves have been used for indigestion and improvement of blood circulation, and as an expectorant. ${ }^{16}$ The chemical constituents and biological activity of various parts of $G$. cowa have been intensively investigated. The major components found were xanthones and qui- none. ${ }^{3}$ Currently, 12 compounds have been isolated from the bark, ${ }^{17}$ leaves ${ }^{18}$ and root. ${ }^{19}$

Previous studies showed that the ethyl acetate fraction of the rinds of asam kandis ( $G$. cowa) have a cytotoxic effect on HeLa cervical cancer cells with $\mathrm{IC}_{50}$ value of $16.194 \pm 3.5019 \mathrm{mg} / \mathrm{mL}$. This fraction is potential to be developed as a new source in developing cancer drugs. Further research is still needed to determine the level of safety in animal experiments. Safety evaluation of the use of traditional medicine should be carried out include the acute toxicity test, sub-acute toxicity test, sub-chronic toxicity test and chronic toxicity test. ${ }^{20}$ This study conducted subacute toxicity tests which aims to determine the safety of the ethyl acetate fraction of asam kandis rinds with determine the toxic effects of chemicals which given repeatedly that potentially in target organs, determine dose-response relationships for the range of the dose and exposure time, as well as for evaluated the maximum dose that does not cause toxic effects on repeated administration..$^{20}$

Liver and kidney function is one of the observations that doing at this toxicity test. Liver is the organ that plays a role in the function of metabolism and excretion from the body. Toxic effects of the drugs are often seen in the liver, because liver metabolizes all drugs and foreign substances that enter the body. 
Liver disorders characterized by elevated serum transaminase activity such SGPT (Serum Glutamic Piruvic Transaminases) in serum. ${ }^{21}$ Kidney also the main target organ of the toxic effect, because its produce urine which is the main route of excretion toxicant and has a high volume of blood flow. One indicator of kidney damage is an increase or a decrease in creatinine levels in the body. ${ }^{22}$

\section{MATERIALS AND METHODS}

\section{Chemicals and Reagents}

Assay kits for kidney and liver function indices were products of Randox Laboratories limited,

United Kingdom. Other chemicals and reagents were all of analytical grade.

\section{Plant Collection, Authentication and Extraction}

Fresh rinds of Garcinia cowa were collected from Batu Busuk, Padang, West Sumatra, Indonesia in August, 2015. The plant was identified and authenticated at the Herbarium Andalas University (ANDA) and was assigned a voucher number FSW-001 after which a voucher specimen was prepared and deposited at the University Herbarium. Fresh Rinds of $G$. cowa were then chopped into small pieces, air-dried at room temperature for 10 days to a constant weight and subsequently pulverized into fine powder. Powder sample (500 g) was soaked in 4 liters of $70 \%$ ethanol for 24 hours. The extract was filtered (with Whatman No. 1 filter paper) and the resulting filtrate was concentrated with a rotary evaporator $\left(40^{\circ} \mathrm{C}\right)$. After that, the product was lyophilized to give $12.0 \mathrm{~g}$ of residue, according to a yield of $2.4 \%$. This was then stored in a desiccator for further use.

\section{Experimental Design}

Healthy Swiss albino mice, 6-8 w old, of either sex, having body weights in the range of $20 \pm 3 \mathrm{~g}$ were procured from the animal house of Faculty of Pharmacy Andalas University. They were randomly divided into different experimental groups. Animals were acclimatized to laboratory conditions for at least one week prior to the start of the experiment. They were provided with commercial food pellets and water ad libitum unless stated otherwise. The study was approved by the Ethics Committee Faculty of Medicine Andalas University.

\section{Sub-acute toxicity study}

The sub-acute toxicity study was performed according to OECD guideline 407. A number of 40 mice were divided into 4 groups. Group I (control group) received a solution of $5 \%$ tween 80 , group II-IV were orally administrated with the ethyl acetate fraction of G. cowa rinds with dose $500 \mathrm{mg} / \mathrm{Kg}$ BW, $1000 \mathrm{mg} / \mathrm{Kg} \mathrm{BW}$, and $2000 \mathrm{mg} / \mathrm{Kg} \mathrm{BW}$ respectively once a day for 7 days, 14 days and 21 days. The level of creatinine serum and SGPT was measured on the $8^{\text {th }}$ day, $15^{\text {th }}$ day and $22^{\text {nd }}$ day. Body weight of animals as well as their food and water consumption was recorded weekly during the study period. The animals were observed signs of intoxication and death during the trial period. The blood samples of all the animals were taken prior to necropsy. The weight ratio of liver and kidney were determined by comparing the weight of the liver and kidneys of mice against weight gain in mice. The data were analyzed by statistical two-way ANOVA followed by Duncan's Multiple Range Test.

\section{RESULTS}

SGPT levels of mice was not significantly affected by the duration of administration ( $p>0.05$ ), but were significantly affected by the dosage ( $p$ $<0.05)$. There was no significant effect between duration of administration and the dosage on the SGPT levels ( $\mathrm{p}>0.05)$ (Table 1).
Creatinine levels of mice were significantly affected by the duration of administration and dosage ( $\mathrm{p}<0.05)$. There is a significant effect of interaction between duration of administration and dosage on the serum creatinine level ( $<<0.05)$ (Table 2 and Figure 1).

The weight ratio of liver were significantly affected by the duration of administration $(\mathrm{p}<0.05)$, but was not significantly affected by the dosage $(p>0.05)$. There is no interaction effect between duration of administration and dosage ( $\mathrm{p}>0.05)$ (Table 3 and Figure 2).

The weight ratio of kidneys were significantly affected by the duration of administration $(\mathrm{p}<0.05)$, but was not influenced significantly by the dosage $(p>0.05)$. There was no significant effect on the interaction between duration of administration and dosage ( $p>0.05)$ (Table 4 and Figure 3 ).

Table 1: The effect of dosage and duration of administration of the ethyl acetate fraction of asam kandis rinds on SGPT level

\begin{tabular}{|c|c|c|c|c|}
\hline \multirow{2}{*}{ Dosage } & \multicolumn{3}{|c|}{ Average levels of SGPT (U/L) } & \multirow{2}{*}{$\begin{array}{c}\text { Average } \\
\text { levels } \\
\text { of SGPT } \\
\text { (U/L) }\end{array}$} \\
\hline & $8^{\text {th }}$ day & $15^{\text {th }}$ day & $22^{\text {nd }}$ day & \\
\hline $\begin{array}{c}\text { Control } \\
\pm \mathrm{SD}\end{array}$ & $27.50 \pm 3.235$ & $37.74 \pm 0.933$ & $36.66 \pm 13.074$ & $33.98 \pm 5.628$ \\
\hline $\begin{array}{c}500 \mathrm{mg} / \\
\mathrm{kg} \mathrm{BW} \pm \\
\mathrm{SD}\end{array}$ & $38.82 \pm 2.801$ & $32.89 \pm 6.537$ & $37.20 \pm 9.805$ & $36.30 \pm 3.066$ \\
\hline $\begin{array}{c}1000 \mathrm{mg} / \\
\mathrm{kg} \mathrm{BW} \pm \\
\mathrm{SD}\end{array}$ & $37.20 \pm 1.617$ & $47.99 \pm 7.644$ & $37.74 \pm 3.367$ & $40.20 \pm 6.076$ \\
\hline $\begin{array}{c}2000 \mathrm{mg} / \\
\mathrm{kg} \mathrm{BW} \pm \\
\text { SD }\end{array}$ & $52.30 \pm 13.565$ & $51.22 \pm 4.070$ & $40.98 \pm 7.293$ & $48.17 \pm 6.249$ \\
\hline $\begin{array}{c}\text { Average } \\
\text { levels of } \\
\text { SGPT } \\
(\mathrm{U} / \mathrm{L})\end{array}$ & $41.17 \pm 10.982$ & $39.90 \pm 7.887$ & $38.01 \pm 1.993$ & \\
\hline
\end{tabular}

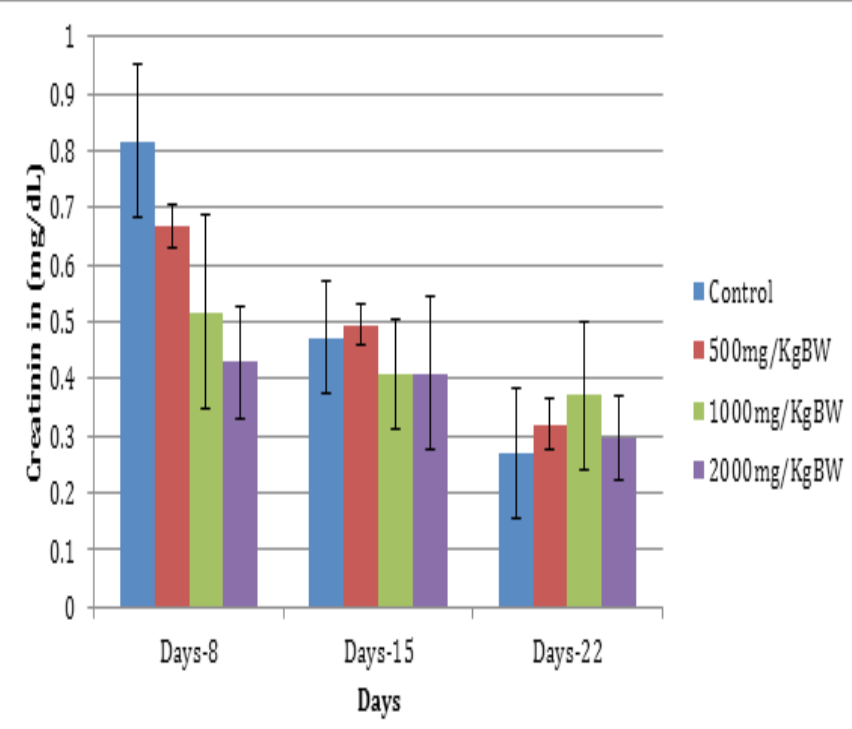

Figure 1: The effect of ethyl acetate fraction of asam kandis rinds on serum creatinine levels of white males mice 
Table 2: The effect of dosage and duration of administration of ethyl acetate fraction of asam kandis rinds on creatinine level

\begin{tabular}{|c|c|c|c|c|}
\hline \multirow{2}{*}{ Dosage } & \multicolumn{3}{|c|}{ Average levels of creatinine $(\mathrm{mg} / \mathrm{dL})$} & \multirow{2}{*}{$\begin{array}{l}\text { Average levels } \\
\text { of creatinine }\end{array}$} \\
\hline & $8^{\text {th }}$ day & $15^{\text {th }}$ day & $22^{\text {nd }}$ day & \\
\hline Control $\pm \mathrm{SD}$ & $0,82 \pm 0,134$ & $0,47 \pm 0,098$ & $0,27 \pm 0,113$ & $0,52 \pm 0,276$ \\
\hline $500 \mathrm{mg} / \mathrm{kgBW} \pm \mathrm{SD}$ & $0,667 \pm 0,037$ & $0,494 \pm 0,037$ & $0,32 \pm 0,043$ & $0,49 \pm 0,173$ \\
\hline $1000 \mathrm{mg} / \mathrm{kgBW} \pm \mathrm{SD}$ & $0,52 \pm 0,170$ & $0,41 \pm 0,098$ & $0,37 \pm 0,128$ & $0,43 \pm 0,076$ \\
\hline $2000 \mathrm{mg} / \mathrm{kgBW} \pm \mathrm{SD}$ & $0,43 \pm 0,098$ & $0,41 \pm 0,134$ & $0,30 \pm 0,074$ & $0,38 \pm 0,072$ \\
\hline $\begin{array}{l}\text { Average levels of } \\
\text { creatinine }\end{array}$ & $0,61 \pm 0,171$ & $0,45 \pm 0,044$ & $0,32 \pm 0,042$ & \\
\hline
\end{tabular}

Table 3: The effect of dosage and duration of administration of ethyl acetate fraction of asam kandis rinds on weight ratio of liver

\begin{tabular}{ccccc}
\hline \multirow{2}{*}{ Dosage } & \multicolumn{3}{c}{ Average weight ratio of liver } & average weight \\
& $8^{\text {th }}$ day & $15^{\text {th }}$ day & $2^{\text {nd }}$ day & $\begin{array}{c}\text { ratio of liver } \pm \\
\text { SD }\end{array}$ \\
\hline Control $\pm \mathrm{SD}$ & $0,061 \pm 0,009$ & $0,046 \pm 0,009$ & $0,042 \pm 0,002$ & $0,049 \pm 0,01$ \\
$500 \mathrm{mg} / \mathrm{kgBW} \pm \mathrm{SD}$ & $0,057 \pm 0,013$ & $0,0399 \pm 0,004$ & $0,048 \pm 0,006$ & $0,048 \pm 0,008$ \\
$1000 \mathrm{mg} / \mathrm{kgBW} \pm \mathrm{SD}$ & $0,06 \pm 0,008$ & $0,051 \pm 0,01$ & $0,047 \pm 0,007$ & $0,053 \pm 0,006$ \\
$2000 \mathrm{mg} / \mathrm{kgBW} \pm \mathrm{SD}$ & $0,063 \pm 0,019$ & $0,045 \pm 0,003$ & $0,046 \pm 0,003$ & $0,051 \pm 0,01$ \\
$\begin{array}{c}\text { average weight ratio of } \\
\text { liver } \pm \mathrm{SD}\end{array}$ & $0,060 \pm 0,002$ & $0,045 \pm 0,004$ & $0,046 \pm 0,003$ & \\
\hline
\end{tabular}

Table 4: The effect of dosage and duration of administration of ethyl acetate fraction of asam kandis rinds on weight ratio of kidneys

\begin{tabular}{|c|c|c|c|c|}
\hline \multirow{2}{*}{ Dosage } & \multicolumn{3}{|c|}{ average weight ratio of kidney } & \multirow{2}{*}{$\begin{array}{l}\text { average weight } \\
\text { ratio of kidney }\end{array}$} \\
\hline & $8^{\text {th }}$ day & $15^{\text {th }}$ day & $22^{\text {nd }}$ day & \\
\hline Control $\pm \mathrm{SD}$ & $0,017 \pm 0,0009$ & $0,012 \pm 0,0003$ & $0,012 \pm 0,0004$ & $0,014 \pm 0,003$ \\
\hline $500 \mathrm{mg} / \mathrm{kgBW} \pm \mathrm{SD}$ & $0,015 \pm 0,0006$ & $0,012 \pm 0,0003$ & $0,012 \pm 0,0006$ & $0,013 \pm 0,008$ \\
\hline $1000 \mathrm{mg} / \mathrm{kgBW} \pm \mathrm{SD}$ & $0,015 \pm 0,0014$ & $0,012 \pm 0,0009$ & $0,013 \pm 0,0012$ & $0,013 \pm 0,002$ \\
\hline $2000 \mathrm{mg} / \mathrm{kgBW} \pm \mathrm{SD}$ & $0,017 \pm 0,0032$ & $0,012 \pm 0,0006$ & $0,013 \pm 0,0013$ & $0,014 \pm 0,003$ \\
\hline $\begin{array}{l}\text { average weight ratio of } \\
\text { kidney }\end{array}$ & $0,016 \pm 0,0012$ & $0,012 \pm 0,0003$ & $0,013 \pm 0,00048$ & \\
\hline
\end{tabular}

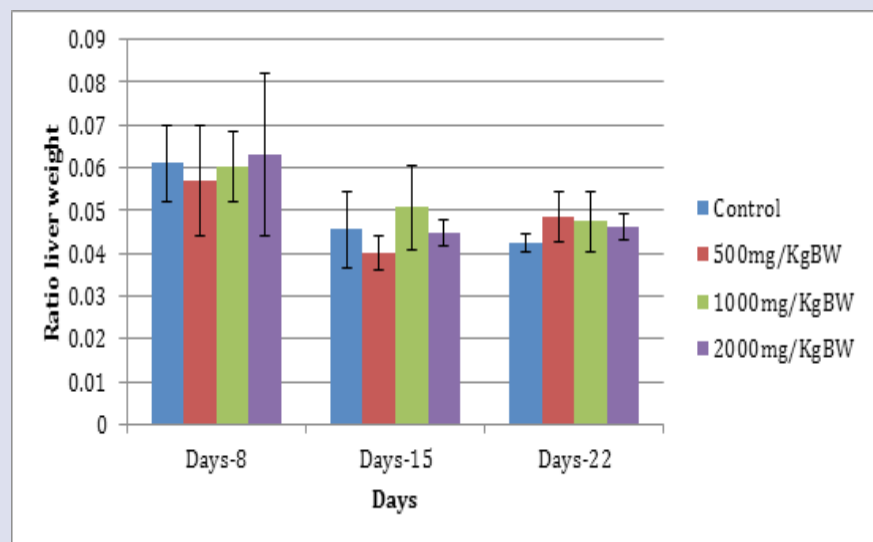

Figure 2: The effect of ethyl acetate fraction of asam kandis rinds on ratio of liver weight of white males mice.

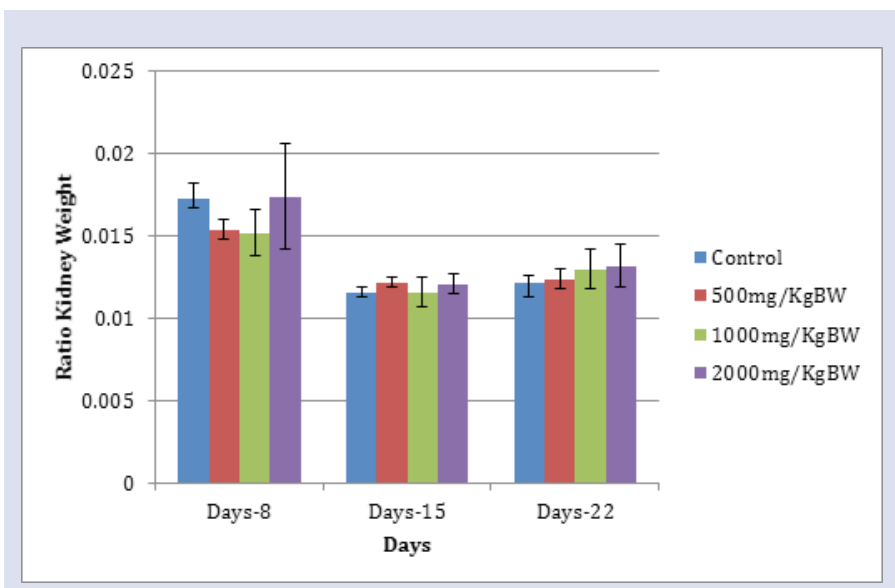

Figure 3: The effect of ethyl acetate fraction of asam kandis rinds on ratio of kidney weight of white males mice. 


\section{DISCUSSION}

Decreased levels of SGPT on $8^{\text {th }}$ day, $15^{\text {th }}$ day and $22^{\text {nd }}$ day is not much different. Decreased levels of SGPT caused by the ability of all cell to be regenerate. Cell regeneration is the process of formation of cells to replace the dead cells. Liver cells having a stable cell. It is estimated that within 5 days the mice cells had regenerated, thus causing a decrease in SGPT levels. ${ }^{22}$ This is the underlying reason for a decline in SGPT levels at $15^{\text {th }}$ day and $22^{\text {nd }}$ day. The average levels of SGPT at dose $2000 \mathrm{mg} /$ $\mathrm{kgBW}$ is higher than the control group, its caused by damage and lysis that happen in liver cells, so SGPT enzyme that located in the cytoplasm will come out and get into the serum, which will increasing SGPT levels. The results of the study did not find any damage to the kidneys of mice. In general, decreased levels of creatinine happen in each group, but still within the normal range of creatinine levels in mice $(0.2$ to $0.9 \mathrm{mg} / \mathrm{dL}){ }^{23}$

The average weight ratio of liver decrease occur in $15^{\text {th }}$ day and $22^{\text {nd }}$ day. It is due to the recovery process by liver cells, because liver cells has the ability to regenerate their cells, which is a process of formation of new cells to replace dead cells. ${ }^{7}$ Liver which exposed with toxicant will lead to death cell. Based on morphology, death of liver cells has two mechanisms, namely, necrosis and apoptosis. Necrosis is the process of death cell that is marked by swelling of cells and release of cell contents. Apoptosis is a process of death cell characterized the occurrence of cell shrinkage, chromatin condensation, nucleus fragmentation, formation of apoptotic bodies and usually do not cause inflammation. ${ }^{7}$ The average weight ratio of liver increased in line with the increase in dose, it can be caused by inflammation and necrosis of the liver cells

A high ratio of kidney on $8^{\text {th }}$ day due to edema or swelling that occurs in kidney. Edema that occurs due to the decrease in blood pressure, thus resulting renin that will change angiostensin I became angiostensin II, resulting in vasoconstriction of the blood vessels, improves water retention, and increased plasma volume. Edema can be caused by a disturbance in glomerular membrane permeability, so that the fluid balance will be disturbed and moved to extracellular. ${ }^{9}$

\section{CONCLUSION}

The dosage of the ethyl acetate fraction of G. cowa rinds provide significant effect on the SGPT and serum creatinine levels of male white mice $(p<0.05)$. The duration of administration of ethyl acetate fraction of asam kandis rinds provides significant effect on serum creatinine levels, the weight ratio of liver and kidney organ of male white mice $(\mathrm{p}<0.05)$

\section{ACKNOWLEDGEMENT}

This research was funded by Universitas Andalas through Hibah Klaster Riset Guru Besar no 23/UN.16/HKRGB/LPPM/2016.

\section{CONFLIC OF INTEREST}

None

\section{ABBREVIATIONS USED}

SGPT: Serum Glutamic Piruvic Transaminases; ANOVA: Analysis of variance; OECD: Organisation for Economic Cooperation and Development.

\section{REFERENCES}

1. Corner EJH Mangosteen family. In: Wayside Trees of Malaysia, Vol. I. Kuala Lumpur, Malayan Nature Society, 1988; pp. 349-57.

2. Burkill IH. A Dictionary of the Economic Products of the Malay Peninsula, Vol. II. Kuala Lumpur, Art Printing Works, 1966; pp. 1063-74.

3. Wahyuni FS, Lindsay TB, Dachriyanus, Dianita R, Jubahar J, Lajis NH, Sargent MV. A new ring-reduced tetraprenyltoluquinone and a prenylated xanthone from Garcinia cowa. Aust J Chem. 2004;57(3):223-6. https://doi.org/10.1071/ $\mathrm{CH} 03175$.

4. Wahyuni FS, Shaari K, Stanslas J, Lajis NH, Dachriyanus, Cytotoxic xanthones from the stem bark of Garcinia cowa Roxb. J Chem Pharm Res. 2015;7(1):22736 .

5. See I, Ee GCL, Teh SS, Mah SH, Karjiban RA, Daud S and Jong VYM, A New Benzophenone from Garcinia benthamiana. Rec Nat Prod. 2016;10(3):355.

6. Jamila N, Khan N, Khan I, Khan AA, Khan SN. A bioactive cycloartane triterpene from Garcinia hombroniana. Nat Prod Res. 2016;30(12):1388-97. https://doi.org/ 10.1080/14786419.2015.1060594 ; PMid:26158779.

7. Michel TK, Ottoh A, Chukwunonye UCE, Obodoike ECO, Christopher O, Maduakolam IM. Bio-flavonoids and Garcinoic Acid from Garcinia kola seeds with Promising Anti-Inflammatory Potentials. Pharmacogn J. 2016;8(1):56-8 ; https:// doi.org/10.5530/pj.2016.1.12.

8. Tan WN, Khairuddean M, Wong KC, Tong WY, Ibrahim D. Antioxidant compounds from the stem bark of Garcinia atroviridis. J Asian Nat Prod Res. 2016; 18(8): 804-811. https://doi.org/10.1080/10286020.2016.1160071; PMid:26999039.

9. Wahyuni FS, Triastuti DH, Arifin H. Cytotoxicity Study of Ethanol Extract of the Leaves of Asam Kandis (Garcinia cowa Roxb.) on T47D Breast Cancer Cell line Pharmacogn J. 2015;7(6):369-71.

10. Husni E, Nahari F, Wirasti Y, Wahyuni FS, Dachriyanus. Cytotoxicity study of ethanol extract of the stem bark of asam kandis (Garcinia cowa Roxb.) on T47D breast cancer cell line, Asian Pac J Trop Biomed. 2015;5(3):249-52. https://doi. org/10.1016/S2221-1691(15)30013-7.

11. Jabit ML, Wahyuni FS, Khalid R, Israf DA, Shaari K, Lajis NH, Stanslas J. Cytotoxic and nitric oxide inhibitory activities of methanol extracts of Garcinia species, Pharm Biol. 2009;47(11):1019-26. https://doi.org/10.3109/13880200902973787.

12. Mahabusarakam W, Mecawun P, Phongpaichit S. Xanthones from the green branch of Garcinia dulcis. Nat Prod Res; 2016;30(20):2323-8. https://doi.org/10. 1080/14786419.2016.1169417; PMid:27055174.

13. Xu X, Shi J, Li L, Zhu D, Yu Z, Yu W, Zhou M, Hu Q, Guo Y, Lou J, Gao X, Liang Deng L. Biphenyls from the Twigs of Garcinia multiflora and their AntiTobacco Mosaic Virus Activities. Rec Nat Prod. 2015;10(5):566-71.

14. Sarma R, Das M, Mudoi T, Sharma KK, Kotoky J, Devi R. Evaluation of Antioxidant and Antifungal Activities of Polyphenol-rich Extracts of Dried Pulp of Garcinia pedunculata Roxb. and Garcinia morella Gaertn. (Clusiaceae). Trop J Pharm Res. 2016;15(1):133-40. https://doi.org/10.4314/tjpr.v15i1.19

15. Mahabusarakam W, Chairerk P, Taylor WC. Xanthones from Garcinia cowa Roxb. Latex. Phytochem. 2005;66:1148-53. https://doi.org/10.1016/j.phytochem.2005.02.025; PMid:15924919.

16. Panthong K, Hutadilok-Towatana N, Panthong A. Cowaxanthone F. a new tetraoxygenated xanthone, and other anti-inflammatory and antioxidant compounds from Garcinia cowa. Can J Chem. 2009;87:1636-40. https://doi.org/10.1139/ V09-123.

17. Wahyuni FS, Shaari K, Stanslas J, Lajis NH, Dachriyanus. Cytotoxic xanthones from the stem bark of Garcinia cowa Roxb. J Chem Pharm Res. 2015;7(1):22736.

18. Wahyuni FS, Shaari K, Stanslas J, Lajis NH, Hamidi D. Cytotoxic compounds from the leaves of Garcinia cowa Roxb. J Appl Pharm Sci. 2015;5(02):006-11. https://doi.org/10.7324/JAPS.2015.50202.

19. Wahyuni FS, Shaari K, Stanslas J, Lajis NH, Hamidi D. Cytotoxic Properties and Complete Nuclear Magnetic Resonance Assignment of Isolated Xanthones from the Root of Garcinia cowa Roxb. Pharmacogn Mag. 2016;12(S1): S52-6. PMid:27041859 PMCid:PMC4792000.

20. Neergheen-Bhujun VS. Underestimating the toxicological challenges associated with the use of herbal medicinal products in developing countries. Bio Med Res Int. 2013;1-9. https://doi.org/10.1155/2013/804086 ; PMid:24163821 PMCid:PMC3791562

21. Singh A, Bhat TK, Sharma OP. Clinical biochemistry of hepatotoxicity. J Clin Toxicol. 2011;S4:001.

22. Agbaje EO, Adeneye AA, Daramola AO. Biochemical and toxicological studies of aqueous extract of Syzigium aromaticum (L.) Merr and amp; Perry (Myrtaceae) in rodents. Afr J Tradit Complementary Altern Med. 2009;6(3):241.

23. Fuchs TC, Frick K, Emde B, Czasch S, Von Landenberg F, Hewitt P. Evaluation of novel acute urinary rat kidney toxicity biomarker for sub acute toxicity studies in preclinical trials. Toxicol Pathol. 2012;40(7):1031-48. https://doi. org/10.1177/0192623312444618; PMid:22581810. 


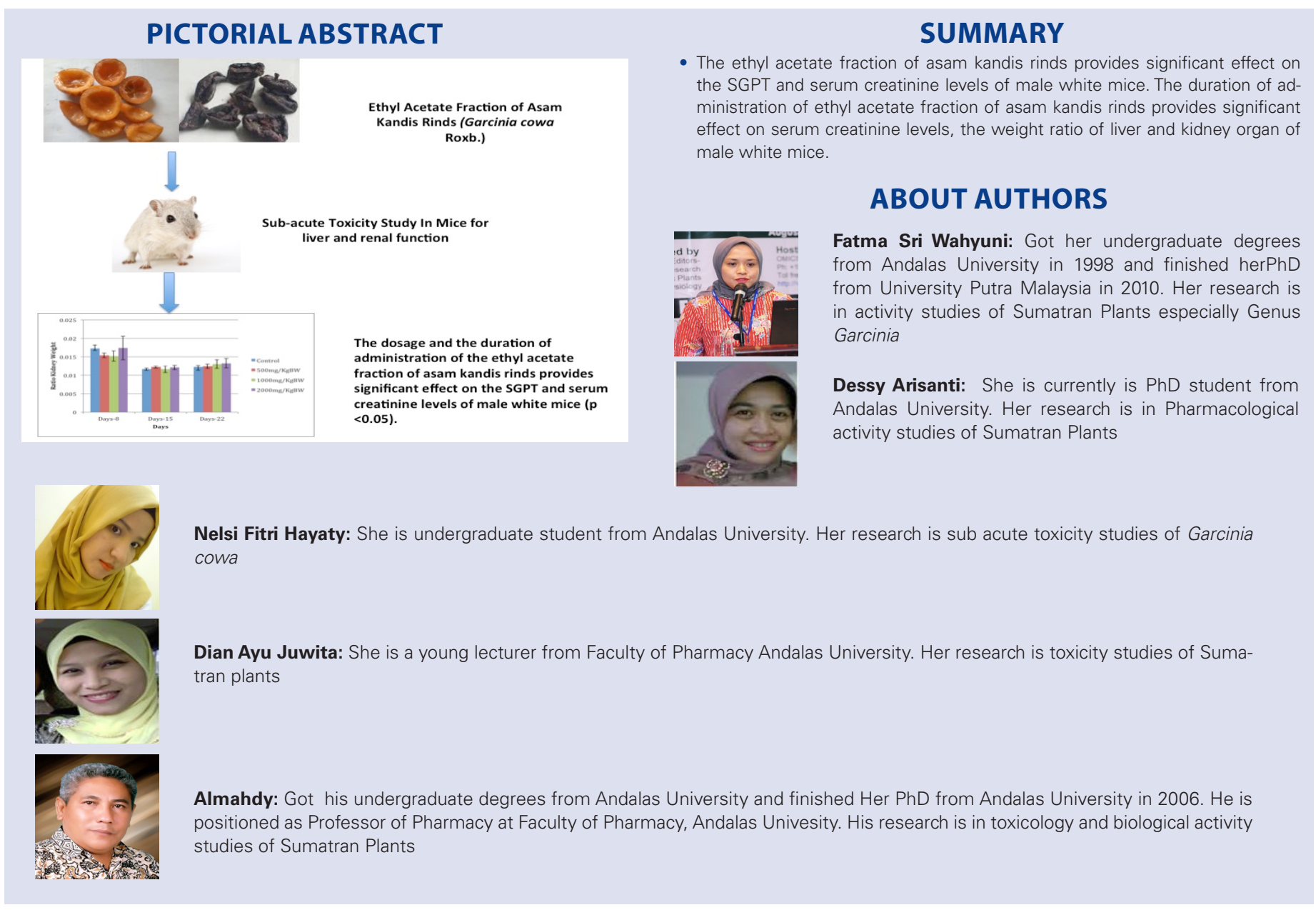

Cite this Article: Wahyuni FS, Arisanty D, Hayaty NF, Juwita DA, Almahdy. Sub-acute Toxicity Study of The Ethyl Acetate Fraction of Asam Kandis Rinds (Garcinia cowa Roxb.) on the Liver and Renal Function in Mice. Pharmacogn J. 2017;9(3):345-9. 